\title{
Characterization of Polysaccharides Extracted from Pulps and Seeds of Crataegus azarolus L. var. aronia: Preliminary Structure, Antioxidant, Antibacterial, $\alpha$-Amylase, and Acetylcholinesterase Inhibition Properties
}

\author{
Ilhem Rjeibi (i), ${ }^{1}$ Rihab Zaabi, ${ }^{2}$ and Warda Jouida ${ }^{2}$ \\ ${ }^{1}$ Research Unit of Macromolecular Biochemistry and Genetics, Faculty of Sciences of Gafsa, 2112 Gafsa, Tunisia \\ ${ }^{2}$ Faculty of Sciences of Gabés, University of Gabés, 6072, Tunisia \\ Correspondence should be addressed to Ilhem Rjeibi; rjeibii@yahoo.fr
}

Received 15 February 2020; Revised 14 April 2020; Accepted 5 May 2020; Published 29 May 2020

Guest Editor: Francisco Jaime B. Mendonça Junior

Copyright (C) 2020 Ilhem Rjeibi et al. This is an open access article distributed under the Creative Commons Attribution License, which permits unrestricted use, distribution, and reproduction in any medium, provided the original work is properly cited.

\begin{abstract}
Polysaccharides from the pulps (CAP) and seeds (CAS) of Crataegus azarolus L. var. aronia were extracted by hot water method. Both polysaccharides were characterized by scanning electron microscopy (SEM), Congo red test, FT-IR spectroscopy, and their antioxidant, $\alpha$-amylase, antiacetylcholinesterase, and antibacterial activities were evaluated. CAP showed the highest total carbohydrate $(82.35 \%)$ and uronic acid $(29.39 \%)$ contents. The Congo red test revealed the lack of triple-helical conformation for both polysaccharides. The comparison of both infrared spectra indicated similar patterns with the presence of typical bands of polysaccharides. However, the microstructure of both samples indicated differences when analyzed by SEM. CAP displayed higher antioxidant, $\alpha$-amylase, and acetylcholinesterase inhibitory activities. Besides, CAP showed the strongest antimicrobial effects against seven microorganisms and, notably, the Gram-positive bacteria. Overall, the results suggest that polysaccharides from C. azarolus L. var. aronia may be considered as novel sources of antioxidants and recommended as enzyme inhibitory agents in food and pharmaceutical industries.
\end{abstract}

\section{Introduction}

Polysaccharides are biomacromolecules widely distributed in algae, plants, animals, and microorganisms. Plant polysaccharides have proved to be potential sources of natural antibacterial, antioxidants, immunomodulatory, antitumor, hepato-cardioprotective, and neuroprotective compounds $[1-3]$. They have been increasingly applied because they are sourced naturally, and they impart less toxicity, biodegradability, and fewer side effects than synthetic ones. Polysaccharides are also widely used as emulsifiers, gelling agents, thickeners, and fat replacers in functional food, cosmetics industries, and biological medicine, including drug delivery and tissue engineering [4]. Over the past decade, there has been a wave of studies into finding new sources of polysaccharides that could hotspot a potential technological interest over existing commercial polysaccharides.
The genus Crataegus spp., which belongs to the Rosaceae, is largely distributed in Africa, North Europe, and North America [5]. This genus is commonly known as hawthorn in English and Zaarour in Arabic. The fruits of Crataegus spp. are commonly eaten as edible food. In addition, fruits, leaves, and flowers have long been used as a traditional medicine to cure various diseases such as asthma, insomnia, flu, coughs, and bronchitis, and headache, respiratory, and cardiovascular problems [6, 7]. Previous research has shown that hawthorn exerts a variety of pharmacological effects, including antioxidant, antidiabetic, antimicrobial, antiviral, anti-inflammatory, antithrombotic, antihyperlipidemic, cardioactive, hepatoprotective, and hypotensive activities [8]. Numerous biochemical studies have demonstrated that hawthorn is a valuable source of bioactive components (e.g., minerals, sugar alcohols, phenolic acids, essential oil, organic acids, tannins, vitamin, flavonoids, and polysaccharides) $[8$, 
9]. Polysaccharides and oligosaccharides extracted from the fruits and flowers of Crataegus spp. possess various human health-promoting effects, such as anticoagulant (for $C$. monogyna) [10] and hypolipidemic activities (for C. pinnatifida) [11]. Likewise, several reports have demonstrated the antioxidant and probiotic properties of polysaccharides extracted from C. pinnatifida $[12,13]$.

Among plant species Crataegus azarolus L. var. aronia (Yellow Azarole) is native to the Mediterranean countries, which have long been used in Tunisian traditional medicines to prevent cancer, diabetes, sexual weakness, and cardiovascular diseases [14]. Previous studies revealed that the leaves, flowers, and fruits of $C$. azarolus had various biological activities including antimicrobial, antioxidant, antihyperglycemic, and antihyperlipidemic activities [15, 16]. These potential health benefits are related to their high content in many natural active compounds, such as flavonoids, minerals, sugar alcohols, carotenoids, polyphenols, amino acids, and tannins [14, 17].

However, to the best of our knowledge, none of the previous studies have focused on the extraction of polysaccharides from C. azarolus L. var. aronia and the evaluation of their antioxidant, antibacterial, $\alpha$-amylase, and acetylcholinesterase inhibition properties. In this study, two polysaccharides from $C$. azarolus were extracted and structurally characterized preliminarily. Then, their biological activities in vitro were evaluated.

\section{Materials and Methods}

2.1. Plant Material. Fresh fruits of Crataegus azarolus L. var. aronia were collected from Gafsa (Northwestern Tunisia, $36^{\circ}$ $46^{\prime} 34^{\prime \prime} \mathrm{N}$ latitude and $8^{\circ} 41^{\prime} 05^{\prime \prime} \mathrm{E}$ longitude) between October and November 2018. The plant was identified by Professor Elkadri Lefi, at the Department of Biology, Faculty of Sciences of Gafsa, Tunisia. A voucher specimen (MSE 0795) was deposited at the herbarium in the Faculty of Sciences Gafsa, Tunisia. The pulps and seeds of the fruits were separated, dried, and crushed individually to obtain a fine powder.

2.2. Extraction of CAS and CAP. The powdered pulps and seeds (60 g, each) were defatted with $95 \%$ ethanol and petroleum ether with continuous stirring for $24 \mathrm{~h}$. The residues were dried and then extracted with hot water at $90^{\circ} \mathrm{C}$ for $5 \mathrm{~h}$ (three-time, $3 \times 5 \mathrm{~h}$ ). Following centrifugation at $4500 \mathrm{rpm}$ for $10 \mathrm{~min}$, the supernatants were mixed with 95\% cold ethanol $(3: 1, v / v)$ at $4^{\circ} \mathrm{C}$ overnight. Precipitates were dissolved in distilled water and deproteinized using Sevag reagent (chloroform/butanol 4:1,v/v). The deproteinized mixture was dialyzed for 3 days (with 3500 Da cut-off, Spectra/Por ${ }^{T M}$, Fisher Scientific, Illkirch, France) and lyophilized to obtain the water-soluble polysaccharides from C. azarolus seeds and pulps named, respectively, CAS and CAP.

Finally, the CAP and CAS extraction yields were calculated.

\subsection{Characterization of CAS and CAP}

2.3.1. Chemical Composition. Total carbohydrates were assessed using the phenol-sulfuric acid method [18], and concentrations were determined against the glucose standard. The total neutral sugar, total phenolic compounds, and uronic acid contents were estimated using, respectively, the sulfuric resorcinol method [19], Folin-Ciocalteu method [20], and $m$-hydroxydiphenyl test [21]. The protein content was determined using the Bradford method [22], and concentrations were estimated against the bovine serum albumin standard. Ash content was determined according to AOAC methods [23].

2.3.2. Infrared Spectroscopic Analysis (FT-IR). CAP and CAS were individually mixed with potassium bromide powder and pressed into pellets. The spectra were analyzed using Fourier transform infrared spectrophotometer (Shimadzu, FT-IR-8400S spectrophotometer equipped with IR solution version 1.10) in the range of $400-4000 \mathrm{~cm}^{-1}$.

2.3.3. Scanning Electron Microscopy. CAP and CAS were examined by scanning electron microscopy (SEM) model JEOL (JSM-IT100). Each dried polysaccharide was mounted on a metal stub and was sputtered with gold. The images were observed at different magnifications (35x and 250x).

2.3.4. Helix-Coil Transition Analysis. The conformational structure of CAP and CAS was analyzed using the Congo red assay [24]. In brief, the two polysaccharides $(2 \mathrm{mg} / \mathrm{mL}$ each) were individually mixed with $2 \mathrm{~mL}$ of $100 \mu \mathrm{M}$ Congo red solution. Different volumes of $\mathrm{NaOH}$ solution $(2 \mathrm{M})$ were added to the mixture to achieve a final concentration of 0 $0.5 \mathrm{M}$. Meanwhile, the solution prepared without adding polysaccharides was considered as the control. The maximum UV-vis absorption was measured from 250 to $550 \mathrm{~nm}$ using Analytik Jena spectrophotometer.

\subsection{Antioxidant Activity}

2.4.1. DPPH Radical Scavenging Activity. The scavenging capacity of CAP and CAS against DPPH radical was assayed using the method of Bersuder et al. [25]. Aliquots of polysaccharides $(500 \mu \mathrm{L})$ at different concentrations $(0.1-4 \mathrm{mg} / \mathrm{mL})$ were mixed with DPPH solution $(125 \mu \mathrm{L}, 0.2 \mathrm{mM})$ and deionized water $(375 \mu \mathrm{L})$, then incubated for $1 \mathrm{~h}$ in the dark. The positive standards (butylated hydroxytoluene and vitamin C) were prepared using the same procedure. The absorbance was measured at $517 \mathrm{~nm}$. The scavenging activity of $\mathrm{DPPH}$ radicals was calculated according to

$$
\text { Scavenging activity }(\%)=\frac{\mathrm{Abs}_{\text {Control }}-\mathrm{Abs}_{\text {Sample }}}{\mathrm{Abs}_{\text {Control }}} \times 100 \text {. }
$$

2.4.2. $\mathrm{H}_{2} \mathrm{O}_{2}$ Scavenging Activity. The scavenging capacity of CAP and CAS against $\mathrm{H}_{2} \mathrm{O}_{2}$ radical was conducted according to the modified procedure of Liu et al. [26]. Briefly, $0.5 \mathrm{~mL}$ of CAP and CAS at various concentrations $(0.1,0.5,1.5,2.5,3$, and $4 \mathrm{mg} / \mathrm{mL}$ ) were individually mixed with $0.1 \mathrm{M}$ phosphate buffer (1.2 mL, $\mathrm{pH} 7.4)$ and $40 \mathrm{mM} \mathrm{H}_{2} \mathrm{O}_{2}$ solution $(0.3 \mathrm{~mL})$, then incubated for $10 \mathrm{~min}$ at room temperature. The positive standard in this assay was vitamin C. The absorbance of each sample was measured at $230 \mathrm{~nm}$. The scavenging activity of $\mathrm{H}_{2} \mathrm{O}_{2}$ radicals was calculated according to Equation (1). 
2.4.3. $\mathrm{Fe}^{2+}$-Chelating Activity. The chelating capacity of ferrous ions by CAP and CAS was assessed using ferrozine reagent procedure as described previously with slight modifications [27]. Solution of polysaccharides $(500 \mu \mathrm{L})$ at different concentrations $(0.1-4 \mathrm{mg} / \mathrm{mL})$ were mixed with $2 \mathrm{mM} \mathrm{FeCl}_{2}$ $(100 \mu \mathrm{L}), 5 \mathrm{mM}$ ferrozine $(200 \mu \mathrm{L})$, and deionized water $(200 \mu \mathrm{L})$ and incubated for $10 \mathrm{~min}$ at $25^{\circ} \mathrm{C}$. In the control solution, the sample was replaced by deionized water. The positive standard in this assay was EDTA (ethylenediaminetetraacetic acid). The ferrous ion chelation activity was calculated according to Equation (1).

2.4.4. Lipid Peroxidation Inhibition Activity. The inhibition effect of CAP and CAS on lipid peroxidation was carried out as described by Yen and Hsieh [28] using mice liver homogenate as the lipid-rich media, $\mathrm{FeCl}_{2}-\mathrm{H}_{2} \mathrm{O}_{2}$ as inducer, and ascorbic acid as the standard. The livers of Swiss albinos mice obtained from the departmental animal house at the Faculty of Sciences Gafsa were dissected, washed, and homogenized into ice-cold Tris- $\mathrm{HCl}$ buffer (1\%, $\mathrm{pH} 7.4$ ). The resulting reaction mixture was centrifuged for $30 \mathrm{~min}$ at $9000 \mathrm{rpm}$ at $4^{\circ} \mathrm{C}$. Aliquots $(500 \mu \mathrm{L})$ were mixed with solutions of polysaccharides $(500 \mu \mathrm{L})$ at different concentrations $(0.5-6 \mathrm{mg} / \mathrm{mL})$, then $50 \mu \mathrm{L}$ of $\mathrm{FeCl}_{2}(0.5 \mathrm{mmol} / \mathrm{L})$ and $\mathrm{H}_{2} \mathrm{O}_{2}$ $(0.5 \mathrm{mmol} / \mathrm{L})$ was added to start lipid peroxidation. After incubation for $30 \mathrm{~min}$ at $37^{\circ} \mathrm{C}$, the trichloroacetic acid $(500 \mu \mathrm{L}, 20 \%)$ was added to precipitate proteins, and the mixture was centrifuged. The thiobarbituric acid ( $1 \mathrm{~mL}, 0.8 \%)$ was added to the obtained supernatant, then heated in boiling water for $9 \mathrm{~min}$. The absorbance of the supernatant was recorded at $532 \mathrm{~nm}$. The inhibition was calculated using

$$
\text { Inhibition rate }(\%)=\frac{1-(\mathrm{A} 1-\mathrm{A} 2)}{\mathrm{A} 0} \times 100
$$

where A0 and A1 were, respectively, the absorbance without and with the test sample, and A2 was the absorbance without liver homogenate.

\subsection{Enzyme Inhibitory Activity Assays}

2.5.1. Acetylcholinesterase Inhibition. The antiacetylcholinesterase effects of CAP and CAS on AChE was analyzed using the modified procedure of Ellman et al. [29]. Briefly, a mixture of $300 \mu \mathrm{L}(50 \mathrm{mM})$ Tris- $\mathrm{HCl}$ buffer $\mathrm{pH} 8,100 \mu \mathrm{L}$ of each polysaccharide, and $30 \mu \mathrm{L}$ AChE solutions was well shaken and incubated for $15 \mathrm{~min}$. Then, $130 \mu \mathrm{L}$ of AChI (acetylthiocholine iodide) and $440 \mu \mathrm{L}$ of $(3 \mathrm{mM})$ DTNB (5,5' -Dithiobis-(2-nitrobenzoic acid)) were added. Galantamine was used as the positive control. The absorbance was measured at $412 \mathrm{~nm}$.

The inhibition activity was calculated using

$$
\text { Inhibition activity }(\%)=\frac{1-\mathrm{ES}}{E} \times 100 \text {. }
$$

ES and $E$ were the respective activity of enzyme with and without the test sample.
2.5.2. $\alpha$-Amylase Inhibition. The $\alpha$-amylase inhibitory activity of CAP and CAS was assessed as described by Oboh et al. [30] with minor modifications. Firstly, $500 \mu \mathrm{L}$ of different concentrations $(0.1-5 \mathrm{mg} / \mathrm{mL})$ of each polysaccharide prepared in PBS $(20 \mathrm{mM})$ were mixed with $\alpha$-amylase $(500 \mu \mathrm{L}, 1.0 \mathrm{U} / \mathrm{mL})$ prepared in $\mathrm{NaCl}(6.0 \mathrm{mM})$ and incubated for $10 \mathrm{~min}$ at $37^{\circ} \mathrm{C}$. Then, potato starch solutions $(500 \mu \mathrm{L}, 1 \%)$ was added to the mixture and re-incubated for $10 \mathrm{~min}$ at $37^{\circ} \mathrm{C}$. Finally, the reaction was stopped using $1 \mathrm{~mL}$ of dinitrosalicylic acid (DNS) reagent and heated in boiling water for $5 \mathrm{~min}$. The absorbance of the resulting mixture was measured at $520 \mathrm{~nm}$. The acarbose was used as the positive control.

The inhibitory activity was estimated as follows:

$$
\text { Inhibition }(\%)=\frac{\mathrm{Abs}_{520} \text { control }-\mathrm{Abs}_{520} \text { sample }}{\mathrm{Abs}_{\mathrm{A} 1} \text { control }} \times 100
$$

\subsection{Antibacterial Activity}

2.6.1. Microorganisms. Microorganisms used in this study represent pathogenic species commonly associated with sanitary relevance. These bacterial organisms, including Gram-positive and Gram-negative, are the main source that causes severe infections in humans. Antibacterial activity of polysaccharides was tested against Grampositive and Gram-negative bacterial strains from the American Type Culture Collection. The test organisms used here are as follows: Escherichia coli (ATCC 35218), Enterococcus faecalis (ATCC 29212), Pseudomonas aeruginosa (ATCC 27853), Listeria monocytogenes (ATCC 19117), Klebsiella pneumoniae (ATCC 13883), Staphylococcus aureus (ATCC 25923), Bacillus cereus (ATCC 11778), and Salmonella typhimurium (ATCC 23564).

2.6.2. Disc Diffusion Assay. Antibacterial activity of CAP and CAS $(15 \mathrm{mg} / \mathrm{mL})$ was performed by disc diffusion method. The suspensions of bacteria $\left(200 \mu \mathrm{L}, 10^{6} \mathrm{CFU} / \mathrm{mL}\right.$, with $\mathrm{CFU} / \mathrm{mL}$ of bacterial cells estimated by absorbance at $600 \mathrm{~nm}$ ) were spread on Mueller-Hinton (MH) agar (Sigma-Aldrich) already cast into Petri dishes. Next, impregnated sterile paper discs (6 mm diameter, $1 \mathrm{~mm}$ thickness) with $10 \mu \mathrm{L}$ of each polysaccharide were deposited individually on Petri dishes, then incubated for $24 \mathrm{~h}$ at $37^{\circ} \mathrm{C}$. The antimicrobial activity was evaluated by measuring the inhibition zone surrounding the discs ( $\mathrm{mm}$ ) using vernier caliper (accuracy $0.02 \mathrm{~mm}$ ). Gentamicin at $20 \mu \mathrm{g} / \mathrm{disc}$ was used as the positive control.

2.6.3. Minimum Inhibitory Concentration (MIC). The MIC of different polysaccharides was performed using the 96-well microdilution method as previously described by Gullon et al. [31]. The microorganism suspension was prepared in order to obtain a final cell density of about $10^{6} \mathrm{CFU} / \mathrm{mL}$. Serial dilutions of each polysaccharide from 1.56 to $25 \mathrm{mg} / \mathrm{mL}$ were prepared using $\mathrm{MH}$ broth. Subsequently, $100 \mu \mathrm{L}$ of the diluted samples were distributed into the microplate. To the above dilutions, equal volumes $(100 \mu \mathrm{L})$ 
TABLE 1: Global composition of CAP and CAS extracted from Crataegus azarolus.

\begin{tabular}{|c|c|c|c|c|c|c|c|}
\hline & $\begin{array}{c}\text { Yield } \\
(\%, w / w)\end{array}$ & $\begin{array}{l}\text { Carbohydrate } \\
(\%, w / w)\end{array}$ & $\begin{array}{l}\text { Neutral } \\
\text { sugar } \\
(\%, w / w)\end{array}$ & $\begin{array}{l}\text { Proteins } \\
(\%, w / w)\end{array}$ & $\begin{array}{l}\text { Uronic acid } \\
(\%, w / w)\end{array}$ & $\begin{array}{l}\text { Polyphenolics } \\
\quad(\%, w / w)\end{array}$ & $\begin{array}{c}\text { Ash } \\
(\%, w / w)\end{array}$ \\
\hline CAP & $6.92 \pm 0.15^{\mathrm{b}}$ & $82.35 \pm 0.23^{b}$ & $52.86 \pm 0.19^{\mathrm{b}}$ & $0.83 \pm 0.01^{b}$ & $29.49 \pm 0.04^{\mathrm{b}}$ & $1.10 \pm 0.01^{\mathrm{b}}$ & $3.03 \pm 0.08^{\mathrm{a}}$ \\
\hline CAS & $2.58 \pm 0.05^{\mathrm{a}}$ & $64.93 \pm 0.41^{\mathrm{a}}$ & $45.25 \pm 0.31^{\mathrm{a}}$ & $5.68 \pm 0.05^{\mathrm{a}}$ & $19.68 \pm 0.10^{\mathrm{a}}$ & $2.13 \pm 0.16^{\mathrm{a}}$ & $3.99 \pm 0.04^{\mathrm{b}}$ \\
\hline
\end{tabular}

Values are means \pm SD of three separate experiments. Different letters indicate a comparison between the two polysaccharides at a level of $p<0.05$.

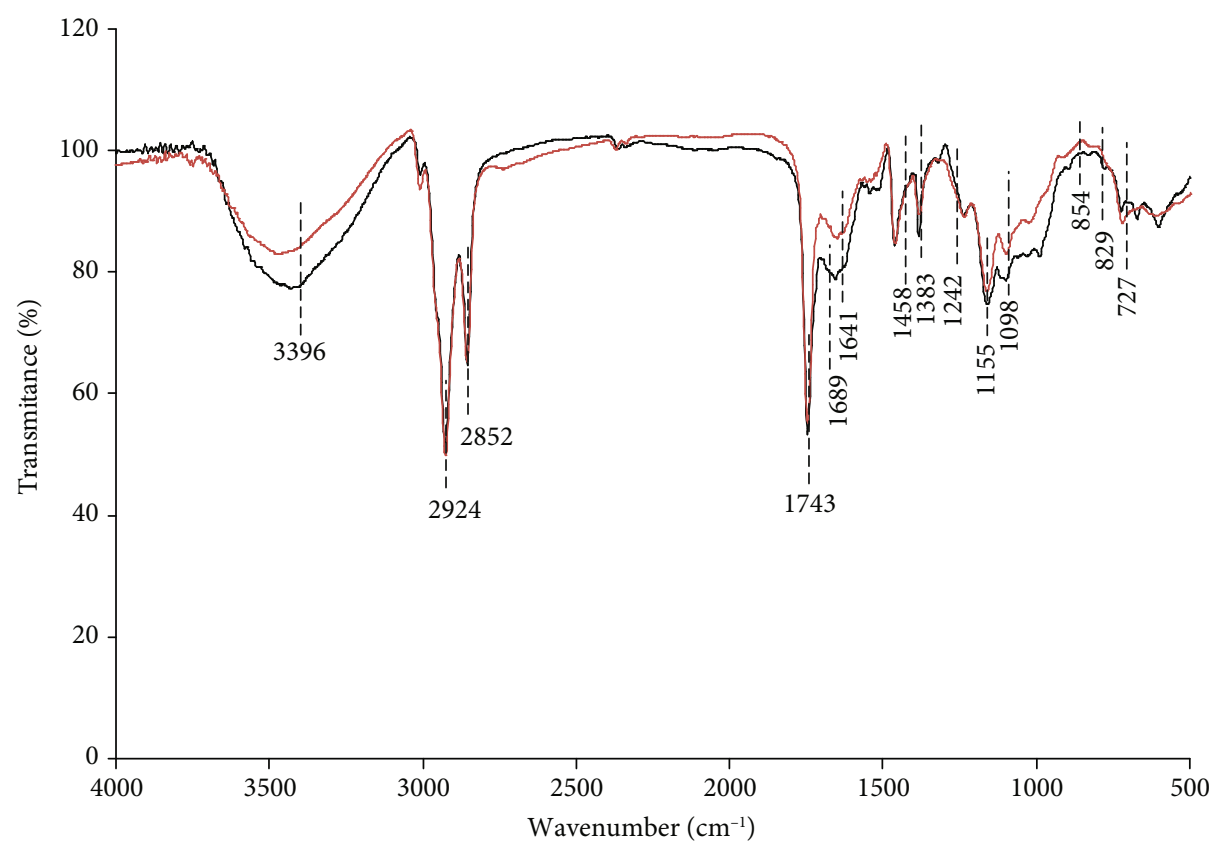

Figure 1: Fourier-transform infrared spectroscopy spectra of CAS and CAP.

of the different bacterial suspensions $\left(10^{6} \mathrm{CFU} / \mathrm{mL}\right)$ were added. Plates were then incubated at $37^{\circ} \mathrm{C}$ for $24 \mathrm{~h}$. The MIC was considered as the lowest concentration of drugs or substances able to inhibit any visible microbial growth.

2.7. Statistical Analysis. Statistical analysis was performed using the SPSS version 18.0 software. All data were analyzed using a one-way analysis of variance (ANOVA) (Tukey test). All values are expressed as mean \pm standard deviation (SD) and $p<0.05$ considered significant.

\section{Results and Discussion}

3.1. Extraction Yields and Physicochemical Property of Polysaccharides. The extraction yields and chemical composition of the crude polysaccharides CAS and CAP obtained from C. azarolus seeds and pulps, respectively, are summarized in Table 1 . The extraction yield of CAP (6.92\%) was higher than that of CAS (2.58\%). Pawlaczyk-Graja [10] reported that the extraction yield of polysaccharides from C. monogyna flowers and fruits ranged from 16.7 to $4.1 \%$. Our results were in line with previous reports suggesting that the differences in species, conditions, and type of extraction procedure could influence the extraction yield of polysaccharides [32]. CAP and CAS showed relative high ash content
(3.08\% in CAP and 3.99\% in CAS). This high content could be related to the presence of residual inorganic salt after the purification of polysaccharides. Protein contents were $0.83 \%$ and $5.68 \%$ for CAP and CAS, respectively. CAP showed $82.35 \%$ of carbohydrate and $52.86 \%$ of neutral sugar contents, which were higher than those of CAS $(64.93 \%$ of carbohydrate and $45.25 \%$ of neutral sugar). Uronic acid contents were $29.49 \%$ for CAP and $19.68 \%$ for CAS suggesting the presence of acidic polysaccharides [33].

3.2. FT-IR Spectrometric Analysis. For quick evaluation of the important functional groups and linkage of polysaccharides, the FT-IR spectrum of CAP and CAS was performed, and results are illustrated in Figure 1. The comparison of both spectra indicated similar patterns. Both spectra showed broad peaks at around $3396 \mathrm{~cm}^{-1}$ which were ascribed to the stretching vibration of hydroxyl groups in the constituent sugar residues [34]. The peaks at approximately 2924 and $1242 \mathrm{~cm}^{-1}$ were related to the $\mathrm{C}-\mathrm{H}$ asymmetric stretching vibration [35]. The peak located at $1537 \mathrm{~cm}^{-1}$ suggested the presence of phenolic groups [36]. The absorbance peaks at about $1743 \mathrm{~cm}^{-1}, 1689 \mathrm{~cm}^{-1}$, and $1522 \mathrm{~cm}^{-1}$ were attributed to carboxyl and carboxylate vibrations, showing the presence of uronic acids $[37,38]$, which was verified by chemical analysis. The region at around $1000-1200 \mathrm{~cm}^{-1}$ indicates the 

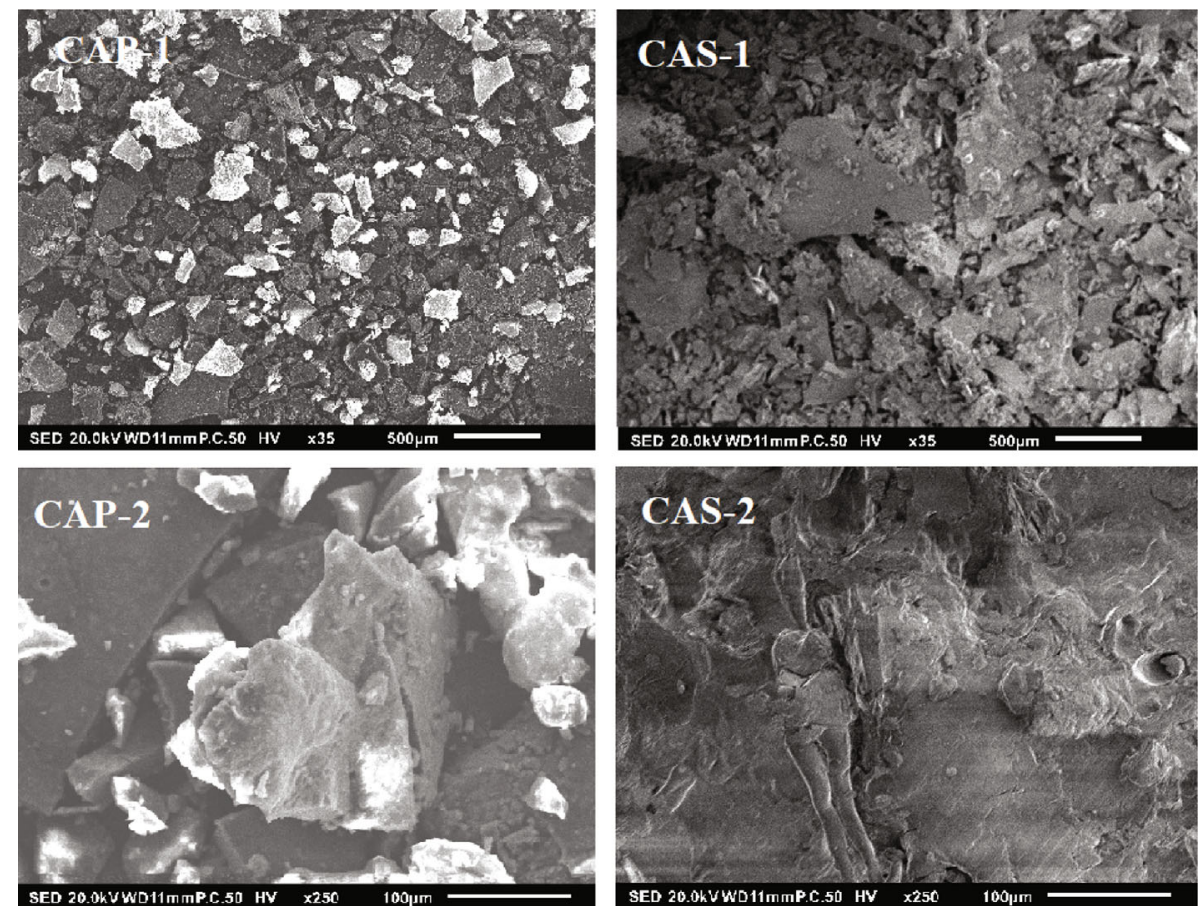

Figure 2: Scanning electron micrographs of polysaccharides from CAP and CAS (1: magnification 35x, scale bar 500 $\mu$ m; 2 : magnification 250x, scale bar $100 \mu \mathrm{m})$.

presence of pyranose [39]. The characteristic absorptions at $854 \mathrm{~cm}^{-1}$ and $921 \mathrm{~cm}^{-1}$ might be attributed to the existence of $\alpha$ and $\beta$ configurations in CAP and CAS [40].

3.3. SEM Analysis. The microstructure of the two samples indicated differences when analyzed by SEM at different magnifications (35x and 250x) (Figure 2). CAS consisted of many small particles in aggregation with irregular shape and dimensions [41], whereas CAP has a relatively uniform surface with schistose substances. Nep and Conway [42] reported that the method of the preparation of the plant material may affect the shape and surface topology of polysaccharides.

3.4. Triple-Helical Conformation Analysis. The Congo red is a sensitive technique to confirm the conformational structure of the polysaccharides as a triple-helical structure [43]. In general, when a polysaccharide with a triple-helical conformation is mixed with Congo red, the $\lambda$ max will shift towards a longer wavelength [33]. But this $\lambda \max$ will decrease rapidly with the increase of $\mathrm{NaOH}$ concentrations (Figure 3). Our results showed that the $\lambda$ max of Congo red-CAP complex and Congo red-CAS complex presented a comparable shift trend as Congo red alone once the concentration of $\mathrm{NaOH}$ increased from 0 to $0.5 \mathrm{~mol} / \mathrm{L}$, suggesting no triple-helical conformation for both polysaccharides.

\subsection{In Vitro Antioxidant Activities Analysis}

3.5.1. DPPH Radical Scavenging Activity. The scavenging rates of DPPH radicals by both polysaccharides increased with the increase of concentrations ranging from 0.1 to $4 \mathrm{mg} / \mathrm{mL}$ (Figure $4(\mathrm{a})$ ). The scavenging effects attained maximum values of $83.2 \%$ and $63.74 \%$ for CAP and CAS, respec-

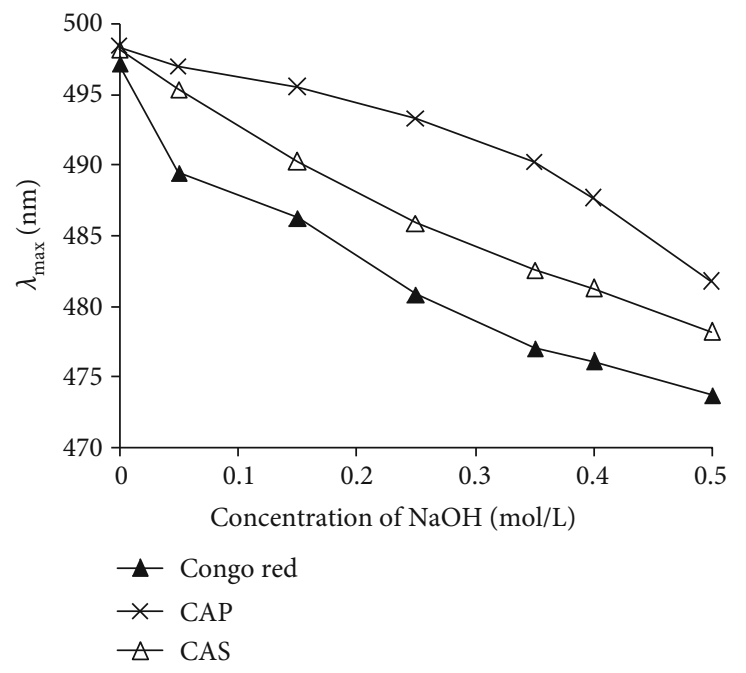

FIGURE 3: Changes in absorption wavelength maximum ( $\lambda \max )$ of CAS and CAP Congo red complex at various $\mathrm{NaOH}$ concentrations. The maximum absorption wavelength of the mixture was determined by ultraviolet scanning $(250-550 \mathrm{~nm})$.

tively, at the concentration of $4 \mathrm{mg} / \mathrm{mL}$. It can be seen that the scavenging capacity of $C$. azarolus polysaccharides to DPPH radicals was similar to other polysaccharides. For example, polysaccharides extracted from Crataegus pinnatifida Bunge $(\mathrm{CPPu})$ have been reported to have a DPPH radical scavenging activity of $87.4 \%$ at a concentration of $5 \mathrm{mg} / \mathrm{mL}$ [44]. CAS had lower efficacy to scavenge DPPH $\left(\mathrm{SC}_{50}=2.56 \mathrm{mg} / \mathrm{mL}\right)$ than CAP $\left(\mathrm{SC}_{50}=1.47 \mathrm{mg} / \mathrm{mL}\right)$. However, the free radical scavenging ability of CAP and CAS was lower than that of the positive control (vitamin $\mathrm{C}, \mathrm{SC}_{50}=0.47 \mathrm{mg} / \mathrm{mL}$ ). The 


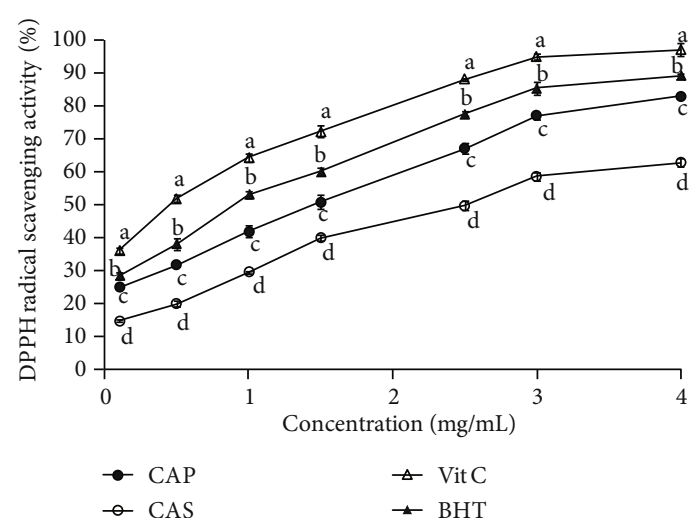

(a)

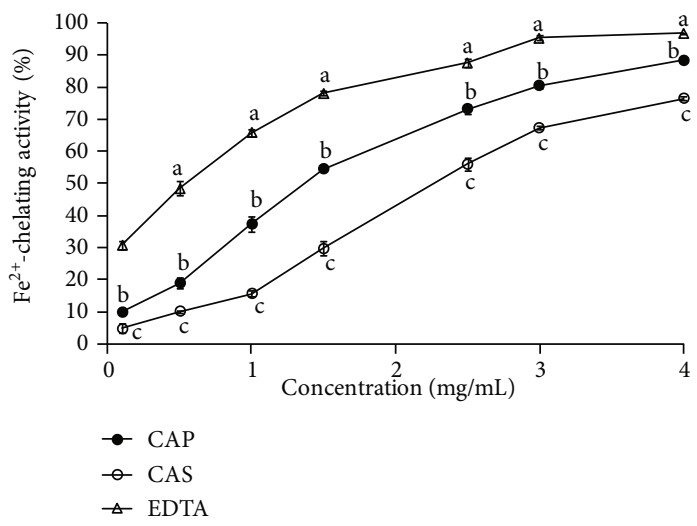

(c)

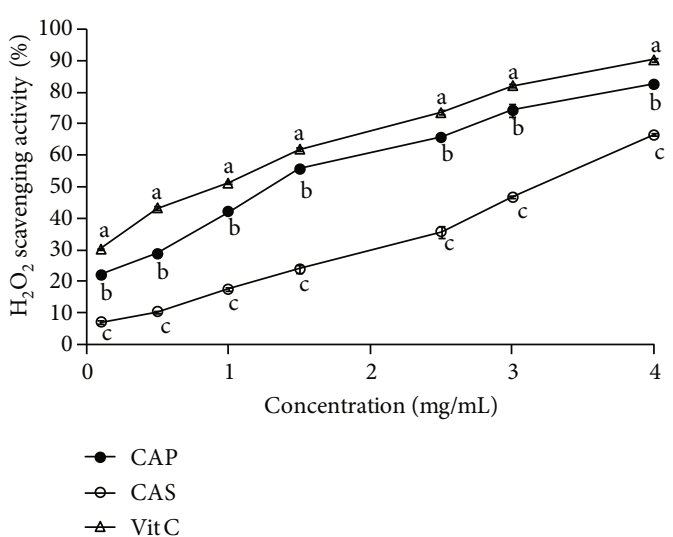

(b)

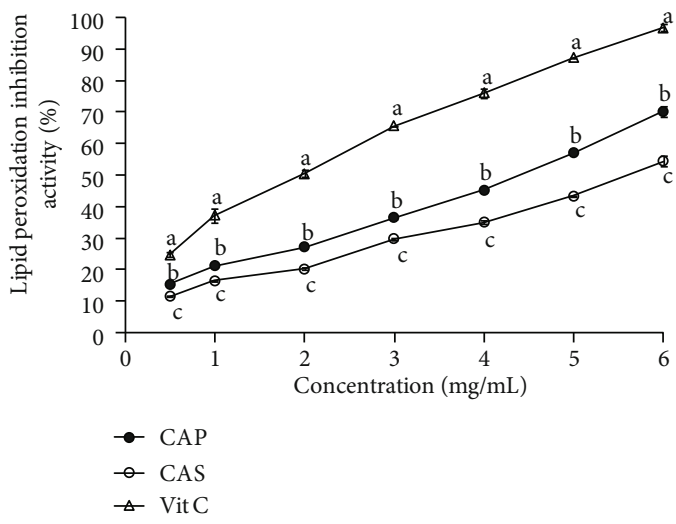

(d)

Figure 4: Antioxidant activities of CAP and CAS with different methods. (a) DPPH scavenging activity; (b) $\mathrm{H}_{2} \mathrm{O}_{2}$ scavenging activity; (c) $\mathrm{Fe}^{2+}$-chelating activity; (d) lipid peroxidation inhibition activity. Positive controls consisted of Vit C, BHT, and EDTA (vitamin C, butylated hydroxytoluene, and ethylenediaminetetraacetic acid, respectively). Each value is expressed as mean \pm SD of three replicates. Different letters represent the significant difference $(p<0.05)$ at the same concentration for different samples.

DPPH radical scavenging ability of CAP and CAS was higher than that of polysaccharide extracted from the fruits of Morus nigra [45] but lower than that from Nitrari retusa fruit polysaccharide [3]. Previous studies suggested that the content of uronic acid is a key factor in the antioxidant effects of polysaccharides $[46,47]$. Our study showed that CAP and CAS contained 29.49 and $19.68 \%$ uronic acid, respectively, which might serve as an important factor in the antioxidant capacity of both polysaccharides. Moreover, Blois [48] has demonstrated that hydroxyl groups are involved in the higher DPPH radical scavenging ability, which was consistent to our study.

3.5.2. $\mathrm{H}_{2} \mathrm{O}_{2}$ Scavenging Activity. $\mathrm{H}_{2} \mathrm{O}_{2}$ scavenging effect of CAP and CAS are illustrated in Figure 4(b). Clearly, there was a dose-dependent relationship between each polysaccharide concentrations and the antioxidant activity. The scavenging efficiencies of CAP, CAS, and vitamin C at $4 \mathrm{mg} / \mathrm{mL}$ were $82.48 \%, 66.51 \%$, and $90.25 \%$, respectively. The $\mathrm{SC}_{50}$ value of the CAP was $1.34 \mathrm{mg} / \mathrm{mL}$, which was 2.39 -fold lower than that of CAS, indicating that CAP is a more potent radical scavenger than CAS. In the literature, there are no studies on the $\mathrm{H}_{2} \mathrm{O}_{2}$ scavenging effect of the Crataegus species presented in the present study. In comparison with polysaccha- rides extracted from the fruits of other species, the antiradical activity of CAP was found near to that of Lycium europaeum $\left(\mathrm{SC}_{50}=1.19 \mathrm{mg} / \mathrm{mL}\right)[49]$ and lower than that of Nitraria retusa $\left(\mathrm{SC}_{50}=2.03 \mathrm{mg} / \mathrm{mL}\right)$ [3]. Previous studies reported that the scavenging abilities of polysaccharides might depend on functional groups as $\mathrm{COOH}$ and $\mathrm{OH}$ present in saccharides structures [50], which was similar to the present study.

3.5.3. Ferrous Ion-Chelating Activity. Metal ions $\left(\mathrm{Cu}^{2+}, \mathrm{Pb}^{2+}\right.$, and $\mathrm{Fe}^{2+}$ ) are well known to be engaged in the generation of free radicals and indirectly contribute to lipid peroxidation and DNA damage. The $\mathrm{Fe}^{2+}$-chelating activity of the CAP and CAS was evaluated, and results are illustrated in Figure 4(c). Both polysaccharides exhibited good concentration-dependent ferrous ion-chelating ability. The chelating potential increased with increasing concentration up to $4 \mathrm{mg} / \mathrm{mL}$ and was always stronger for CAP than CAS. This might be due to a stronger chelating ability for CAP compared to CAS. At $4 \mathrm{mg} / \mathrm{mL}$, the chelating potential of CAP, CAS, and EDTA were $88.43 \%, 76.53 \%$, and $96.76 \%$, respectively. The $\mathrm{EC}_{50}$ values of CAP and CAS were 1.38 and $2.28 \mathrm{mg} / \mathrm{mL}$, respectively, which were higher than that of EDTA $(0.51 \mathrm{mg} / \mathrm{L})$. In the literature, there are no studies 


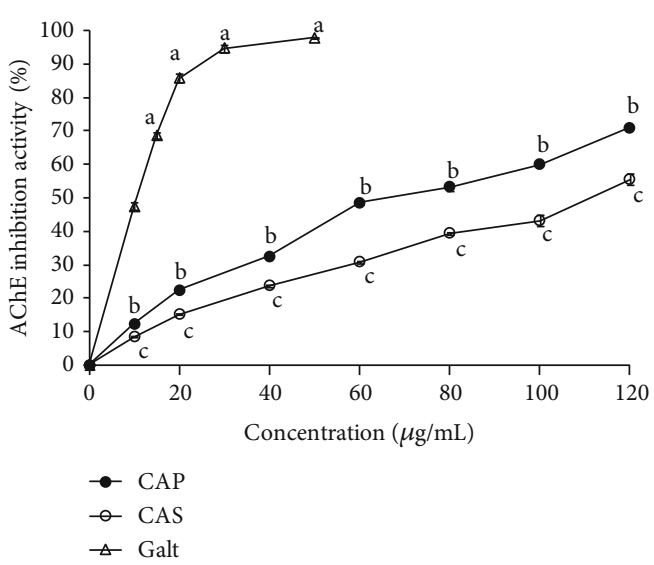

(a)

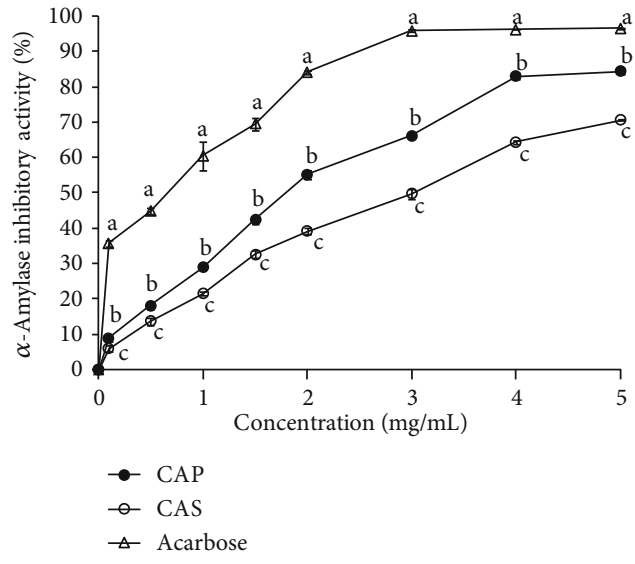

(b)

FIGURE 5: Enzyme inhibitory activities of CAP and CAS with various concentrations. (a) AChE inhibitory activity; (b) $\alpha$-amylase inhibitory activity. Each value is expressed as mean \pm SD of three replicates. Different letters represent the significant difference $(p<0.05)$ at the same concentration for different samples.

on the $\mathrm{Fe}^{2+}$-chelating activity of the Crataegus species presented in the present study. The ferrous ion-chelating ability of CAP was found to be close to that of polysaccharides extracted from Malva aegyptiaca $\left(\mathrm{EC}_{50}=1.15 \mathrm{mg} / \mathrm{mL}\right)$ [51]. It has been reported that biomolecules including some functional groups like $\mathrm{COH}$ can easily chelate ferrous $\left(\mathrm{Fe}^{2+}\right)$ ions. In addition, the substances, which own two or more functional groups of $\mathrm{OH}, \mathrm{COOH}, \mathrm{SH}, \mathrm{S}, \mathrm{CO}$, and $\mathrm{O}$, had a structurefunction relationship [52]. Accordingly, the chelating activity of CAP and CAS might be in part linked to the presence of the strong $\mathrm{Fe}^{2+}$-chelating groups in their structure.

3.5.4. Liver Lipid Peroxidation Inhibition Activity. Lipid peroxidation is widely recognized as a key process in diverse diseases [26]. In the literature, there are no studies on the lipid peroxidation inhibition activity of the Crataegus species presented in the present study. The effects of both polysaccharides on $\mathrm{FeCl}_{2}-\mathrm{H}_{2} \mathrm{O}_{2}$-induced lipid peroxidation in mice liver are illustrated in Figure 4(d). The result showed that liver lipid peroxidation was effectively inhibited by CAS and CAP at all tested concentrations. At $6 \mathrm{mg} / \mathrm{mL}$, the inhibition effects of CAP, CAS, and vitamin C were $70.07 \%$, $54.32 \%$, and $96.57 \%$, respectively. The $\mathrm{EC}_{50}$ values of the CAP and CAS were 4.44 and $5.52 \mathrm{mg} / \mathrm{mL}$, respectively, which were lower than that of vitamin $\mathrm{C}(2.29 \mathrm{mg} / \mathrm{mL})$. It has been documented that the protective effects of natural antioxidants (like polysaccharides) on lipid peroxidation induced by $\mathrm{Fe}^{2+} / \mathrm{H}_{2} \mathrm{O}_{2}$ system might be assigned to their scavenging abilities on $\mathrm{H}_{2} \mathrm{O}_{2}$ and $\mathrm{OH}$ radical [53]. Another report [26] revealed that polysaccharides with high metal ion-chelating activities are able to inhibit peroxidation by interfering with the free radical reaction chains.

\subsection{Enzyme Inhibitory Activity Assays}

3.6.1. Acetylcholinesterase (AChE) Inhibition. Alzheimer's disease $(\mathrm{AD})$ is an example of a neurodegenerative disease which affects the memory. One of the goals of $\mathrm{AD}$ treatment is to increase the level of acetylcholine in the brain by inhibit- ing the activity of AChE [54]. Due to the lack of effective treatments for $\mathrm{AD}$ and the considerable side effects associated with the use of neuroprotective drugs, researchers are constantly looking for new and more effective therapies from medicinal plants to improve the loss of neuronal cells and brain restoration [55, 56]. Natural antioxidants have been often evinced to have beneficial effects in the prevention of memory impairment. Several investigations have demonstrated the neuroprotective and antioxidant effects of phenolic compounds extracted from hawthorn seeds [57, 58]. These properties were explained by their inhibitory effects on lipid peroxidation and free radicals. Other studies have demonstrated the anticholinesterase activity of phenolic compounds isolated from C. oxyacantha [59]. However, the enzyme inhibitory effect of polysaccharides from these plants has not yet been reported. In this study, the effects of both polysaccharides extracted from $C$. azarolus on AChE inhibitory activities are presented in Figure 5(a). The inhibitory effect of CAP and CAS was proportional to the concentration $(10-120 \mu \mathrm{g} / \mathrm{mL})$. The inhibitory effect of CAS was $55.46 \%$ at a concentration of $120 \mu \mathrm{g} / \mathrm{mL}$, which was weaker than the CAP (71.03\%) under the same concentration. As summarized in Table 2, CAP displayed important AChE inhibitory activity $\left(\mathrm{EC}_{50}=61.56 \mu \mathrm{g} / \mathrm{mL}\right)$ as compared to CAS $\left(\mathrm{EC}_{50}=115.94 \mu \mathrm{g} / \mathrm{mL}\right)$. In this study, the anticholinesterase drug galantamine (an alkaloid isolated from the bulbs and flowers of Galanthus caucasicus and FDAapproved drug) was used as a positive control. Results showed that the activity of CAP was less than that of galantamine $\left(\mathrm{EC}_{50}=10.53 \mu \mathrm{g} / \mathrm{mL}\right)$. AChE inhibitory activity of CAP and CAS were higher than those of Physalis alkekengi and Flammulina velutipes polysaccharides [60, 61]. This implies that CAS and CAP could be potential inhibitors of $\mathrm{AChE}$ and beneficial for human memory. The modulation of the cholinergic system could be one of the pharmacological mechanisms used by Crataegus to improve memory problems. In this inhibitory mechanism, polysaccharides 
TABLE 2: Inhibition activity ( $\mathrm{IC}_{50}$ values) of CAS and CAP on studied enzymes.

\begin{tabular}{|c|c|c|c|c|}
\hline & CAP & CAS & Galantamine & Acarbose \\
\hline$\overline{\mathrm{AChE}}\left(\mathrm{IC}_{50}, \mu \mathrm{g} / \mathrm{mL}\right)$ & $61.56 \pm 0.64^{\mathrm{b}}$ & $115.94 \pm 4.68^{\mathrm{c}}$ & $10.53 \pm 0.23^{\mathrm{a}}$ & - \\
\hline$\alpha$-Amylase $\left(\mathrm{IC}_{50}, \mathrm{mg} / \mathrm{mL}\right)$ & $1.81 \pm 0.03^{\mathrm{b}}$ & $3.01 \pm 0.08^{\mathrm{c}}$ & - & $0.82 \pm 0.04^{\mathrm{a}}$ \\
\hline
\end{tabular}

Values are means \pm SD of three separate experiments. Different letters indicate a comparison between the samples at a level of $p<0.05$.

TABLE 3: The antimicrobial activity and MICs of CAP and CAS.

\begin{tabular}{|c|c|c|c|c|}
\hline \multirow{2}{*}{ Microorganism } & \multicolumn{2}{|c|}{ Diameters of inhibition zone (mm) } & \multicolumn{2}{|c|}{ MICs $(\mathrm{mg} / \mathrm{mL})$} \\
\hline & CAP & CAS & CAP & CAS \\
\hline \multicolumn{5}{|l|}{ Gram negative } \\
\hline Escherichia coli (ATCC 35218) & $12.48 \pm 0.02$ & $11.25 \pm 0.05$ & 3.12 & 6.25 \\
\hline Klebsiella pneumoniae (ATCC 13883) & $10.16 \pm 0.04$ & $9.16 \pm 0.07$ & 6.25 & 12.5 \\
\hline Salmonella typhimurium (ATCC 23564) & $13.21 \pm 0.01$ & $11.62 \pm 0.02$ & 1.56 & 3.12 \\
\hline \multicolumn{5}{|l|}{ Gram positive } \\
\hline Bacillus cereus (ATCC 11778) & $14.49 \pm 0.01$ & $8.61 \pm 0.02$ & 1.56 & 3.12 \\
\hline Listeria monocytogenes (ATCC 19117) & $16.65 \pm 0.05$ & $11.4 \pm 0.11$ & $<1.56$ & 1.56 \\
\hline Staphylococcus aureus (ATCC 25923) & $12.36 \pm 0.04$ & $10.15 \pm 0.05$ & 3.12 & 6.25 \\
\hline Enterococcus faecalis (ATCC 29212) & $13.95 \pm 0.05$ & $11.66 \pm 0.04$ & 3.12 & 1.56 \\
\hline
\end{tabular}

MIC: minimum inhibitory concentration. Values are means \pm SD of three separate experiments.

(inhibitors) bind to the same active site as the enzyme substrate, and this implies a nonmetabolizable response [62].

3.6.2. $\alpha$-Amylase Inhibition. Among the available procedures, inhibition of $\alpha$-amylase has seemed to be an important therapeutic target for the prevention and management of type 2 diabetes mellitus [63]. When the activity of $\alpha$-amylase is inhibited, the increase of blood glucose concentrations can be delayed. There were a few researches on the inhibition activity of $\alpha$-amylase by Crataegus sp. extracts [8]. As far as we know, the present study is the first to describe the in vitro antidiabetic effects of polysaccharides from C. azarolus. As illustrated in Figure 5(b), both polysaccharides displayed $\alpha$-amylase inhibitory activity in a dose-dependent manner at the range from 0.1 to $5.0 \mathrm{mg} / \mathrm{mL}$. The $\mathrm{EC}_{50}$ value of CAP was about $1.81 \mathrm{mg} / \mathrm{mL}$, which was more effective than that of CAS $\left(\mathrm{EC}_{50}=3.01 \mathrm{mg} / \mathrm{mL}\right)$ but less effective than that of acarbose $\left(\mathrm{EC}_{50}=0.82 \mathrm{mg} / \mathrm{mL}\right)$ (Table 2). The inhibitory effects of polysaccharides from C. azarolus were similar to that from Diaphragma juglandis fructus [64], but also more efficient than that from Corbicula fluminea [65] and blackcurrant fruits [66], which have been demonstrated as potent antihyperglycemic agents in vivo. Authors have suggested that the high antihyperglycemic capacity of polysaccharides was related to their structure, the configuration of glycosidic bonds, monosaccharide composition, and the high uronic acid content. Other studies have shown that the inhibition mechanism could be that the carboxyl group and the hydroxyl group of polysaccharides could react with the amino acid residues of the digestive enzymes, which caused a reduction in the $\alpha$-amylase activity [67].

3.7. Antimicrobial Activity. Antimicrobial activity of CAP and CAS tested against seven microorganisms is summarized in Table 3. The result evidenced that the antibacterial effect of both polysaccharides varied with bacterial species. The inhibition zone diameter of the two polysaccharides against tested bacteria ranged from 10.16 to $16.65 \mathrm{~mm}$ and from 8.61 to $11.66 \mathrm{~mm}$ for CAP and CAS, respectively. CAP revealed the best antimicrobial effect against $L$. monocytogenes and B. cereus. However, CAS displayed the highest inhibition activity toward E. faecalis. Moderate antibacterial activity was observed against $K$. pneumoniae with inhibition zones of 10.16 and $9.16 \mathrm{~mm}$ for CAP and CAS, respectively. The antimicrobial activity of polysaccharides was also estimated as minimal inhibitory concentration (MIC) (Table 3). Results proved that Gram-positive bacteria were more sensitive to both polysaccharides than Gram-negative. These findings were in accordance with previously published searches $[68,69]$. They reported that the outer membrane of Gram (-) bacteria may act as a barrier against hyperacidification, which would result in differences in the resistance of Gram-positive and Gram-negative bacteria to the action of antimicrobial drugs. The mechanisms related to the antimicrobial activity of polysaccharides were still not clear and deserve to be deepened. The broad-spectrum antimicrobial potential of CAP and CAS may be explained by their higher total sugar contents [48]. He et al. [70] reported that the inhibition effect of polysaccharides may be explained by their abilities to induce the disruption of the cell wall of bacteria and to enhance ion permeability leading cell death. Further, DNA might be decomposed into small fragment after the polysaccharide has penetrated into the cell, which can make the bacteria unable to develop resistance. The best activity against Listeria monocytogenes was observed with CAP $(\mathrm{MIC}<1.56 \mathrm{mg} / \mathrm{mL})$. In the literature, there are no studies on the antimicrobial activity of the Crataegus species presented in the present study. The results of MICs denoted that 
MIC values of polysaccharides from C. azarolus found in this study were lower than those obtained in previous findings, which were on the order of 6.25 and $25 \mathrm{mg} / \mathrm{mL}$ for polysaccharide from Saussurea controversa and from 3.12 to $100 \mathrm{mg} / \mathrm{mL}$ for polysaccharide from Lallemantia royleana, respectively $[71,72]$.

\section{Conclusion}

In the present study, two polysaccharides (CAP and CAS) were extracted from C. azarolus fruits, and their physiochemical properties were characterized using FT-IR, SEM, and Congo red test. Results of FT-IR analysis indicated that CAP and CAS have similar functional groups that are typical of polysaccharides. Both polysaccharides were devoid of helical conformation. CAP had the highest $\mathrm{H}_{2} \mathrm{O}_{2}$ and DPPH radicals scavenging activities and maximum chelating activity on ferrous ion. In vitro CAP remarkably decreased liver lipid peroxidation levels induced by $\mathrm{FeCl}_{2}-\mathrm{H}_{2} \mathrm{O}_{2}$. Both polysaccharides successfully inhibited AChE and $\alpha$-amylase activities and exhibited effective antimicrobial properties against seven pathogenic bacteria. Altogether, our studies suggest that C. azarolus fruits can be further used in food production as a useful natural antioxidant ingredient. Nevertheless, additional studies deserve to be carried out which will elucidate a clear structure-activity relationship.

\section{Data Availability}

All data included in this study are available upon request by contacting the corresponding author.

\section{Conflicts of Interest}

The authors declare that there is no conflict of interest.

\section{Acknowledgments}

We greatly appreciate the technical support provided by the Unit of Common Services, Faculty of Sciences Gafsa, Tunisia.

\section{References}

[1] J. H. Xie, M. L. Jin, G. A. Morris et al., "Advances on bioactive polysaccharides from medicinal plants," Critical Reviews in Food Science and Nutrition, vol. 56, pp. 60-84, 2016.

[2] D. Wei, T. Chen, M. Yan et al., "Synthesis, characterization, antioxidant activity and neuroprotective effects of selenium polysaccharide from Radix hedysari," Carbohydrate Polymers, vol. 125, pp. 161-168, 2015.

[3] I. Rjeibi, A. Feriani, F. Hentati, N. Hfaiedh, P. Michaud, and G. Pierre, "Structural characterization of water-soluble polysaccharides from Nitraria retusa fruits and their antioxidant and hypolipidemic activities," International Journal of Biological Macromolecules, vol. 129, pp. 422-432, 2019.

[4] D. Bais, A. Trevisan, R. Lapasin, P. Partal, and C. Gallegos, "Rheological characterization of polysaccharide-surfactant matrices for cosmetic O/W emulsions," Journal of Colloid and Interface Science, vol. 290, no. 2, pp. 546-556, 2005.
[5] K. L. Christensen, "A biometric study of some hybridizing Crataegus populations in Denmark," Nordic Journal of Botany, vol. 2, no. 6, pp. 537-548, 1983.

[6] R. Bahri-Sahloul, R. Ben Fredj, N. Boughalleb et al., "Phenolic composition and antioxidant and antimicrobial activities of extracts obtained from Crataegus azarolus L. var. aronia (Willd.) Batt. ovaries calli," Journal of Botany, vol. 2014, 11 pages, 2014.

[7] M. Hanus, J. Lafon, and M. Mathieu, "Double-blind, randomised, placebo-controlled study to evaluate the efficacy and safety of a fixed combination containing two plant extracts (Crataegus oxyacantha and Eschscholtzia californica) and magnesium in mild-to-moderate anxiety disorders," Current Medical Research and Opinion, vol. 20, pp. 63-71, 2008.

[8] D. Kumar, V. Arya, Z. A. Bhat, N. A. Khan, and D. N. Prasad, "The genus Crataegus: chemical and pharmacological perspectives," Revista Brasileira de Farmacognosia, vol. 22, no. 5, pp. 1187-1200, 2012.

[9] J. E. Edwards, P. N. Brown, N. Talent, T. A. Dickinson, and P. R. Shipley, "A review of the chemistry of the genus Crataegus," Phytochemistry, vol. 79, pp. 5-26, 2012.

[10] I. Pawlaczyk-Graja, "Polyphenolic-polysaccharide conjugates from flowers and fruits of single- seeded hawthorn (Crataegus monogyna Jacq.): chemical profiles and mechanisms of anticoagulant activity," International Journal of Biological Macromolecules, vol. 116, pp. 869-879, 2018.

[11] R. G. Zhu, Y. D. Sun, T. P. Li et al., "Comparative effects of hawthorn (Crataegus pinnatifida Bunge) pectin and pectin hydrolyzates on the cholesterol homeostasis of hamsters fed high-cholesterol diets," Chemico-Biological Interactions, vol. 238, pp. 42-47, 2015.

[12] S. Zhang, C. Zhang, M. Li, X. Chen, and K. Ding, "Structural elucidation of a glucan from Crataegus pinnatifida and its bioactivity on intestinal bacteria strains," International Journal of Biological Macromolecules, vol. 128, pp. 435-443, 2019.

[13] S. Jeong, R. Tulasi, and S. Koyyalamudi, "Antioxidant capacities of hot water extracts and endopolysaccharides of selected Chinese medicinal fruits," Cancers, vol. 8, no. 3, p. 33, 2016.

[14] R. Bahri-Sahloul, S. Ammar, S. Grec, and F. Harzallah-Skhiri, "Chemical characterisation of Crataegus azarolus L. fruit from 14 genotypes found in Tunisia," Journal of Horticultural Science and Biotechnology, vol. 84, pp. 23-28, 2015.

[15] M. Belkhir, O. Rebai, K. Dhaouadi, B. Sioud, M. Amri, and S. Fattouch, "Antioxidant and antimicrobial activities of Tunisian azarole (Crataegus Azarolus L.) leaves and fruit pulp/peel polyphenolic extracts," International Journal of Food Properties, vol. 16, no. 6, pp. 1380-1393, 2013.

[16] E. Abu-Gharbieh and N. G. Shehab, "Therapeutic potentials of Crataegus azarolus var. eu- azarolus Maire leaves and its isolated compounds," BMC Complementary and Alternative Medicine, vol. 17, no. 1, p. 218, 2017.

[17] A. Yahyaoui, M. O. Arfaoui, G. Rigane et al., "Investigation on the chemical composition and antioxidant capacity of extracts from Crataegus azarolus L.: effect of growing location of an important Tunisian medicinal plant," Chemistry Africa, vol. 2, no. 3, pp. 361-365, 2019.

[18] M. Dubois, K. A. Gilles, J. K. Hamilton, P. Rebers, and F. Smith, "Colorimetric method for determination of sugars and related substances," Analytical Chemistry, vol. 28, no. 3, pp. 350-356, 1956. 
[19] M. Monsigny, C. Petit, and A. C. Roche, "Colorimetric determination of neutral sugars by a resorcinol sulfuric acid micromethod," Analytical Chemistry, vol. 175, pp. 525-530, 1988.

[20] V. L. Singleton, R. Orthofer, and R. M. Lamuela-Raventós, "Analysis of total phenols and other oxidation substrates and antioxidants by means of folin-ciocalteu reagent," Method in Enzymology, vol. 299, pp. 152-178, 1999.

[21] N. Blumenkrantz and G. Asboe-Hansen, "New method for quantitative determination of uronic acids," Analytical Chemistry, vol. 54, pp. 484-489, 1973.

[22] M. M. Bradford, "A rapid and sensitive method for the quantitation of microgram quantities of protein utilizing the principle of protein-dye binding," Analytical Chemistry, vol. 72, pp. 248-254, 1976.

[23] Association of Official Analytical Chemists-AOAC, Official Method of Analysis of AOAC Method 996.11, AOAC International, Gaithersburg, MD, USA, 18th edition, 2005.

[24] D. Rout, S. Mondal, I. Chakraborty, and S. S. Islam, “The structure and conformation of a water-insoluble $(1 \rightarrow 3)-,(1 \rightarrow 6)-\beta$ d-glucan from the fruiting bodies of Pleurotus florida," Carbohydrate Research, vol. 343, no. 5, pp. 982-987, 2008.

[25] P. Bersuder, M. Hole, and G. Smith, "Antioxidants from a heated histidine-glucose model system. I: investigation of the antioxidant role of histidine and isolation of antioxidants by high-performance liquid chromatography," Journal of American Oil Chemists' Society, vol. 75, no. 2, pp. 181187, 1998.

[26] J. Liu, J. Luo, H. Ye, Y. Sun, Z. Lu, and X. Zeng, "In vitro and in vivo antioxidant activity of exopolysaccharides from endophytic bacterium Paenibacillus polymyxa EJS-3," Carbohydrate Polymers, vol. 82, no. 4, pp. 1278-1283, 2010.

[27] N. R. Perron, H. C. Wang, S. N. DeGuire, M. Jenkins, M. Lawson, and J. L. Brumaghim, "Kinetics of iron oxidation upon polyphenol binding," Dalton Transactions, vol. 39, no. 41, pp. 9982-9987, 2010.

[28] G. C. Yen and C. L. Hsieh, "Antioxidant activity of extracts from Du-zhong (Eucommia ulmoides) toward various lipid peroxidation models in vitro," Journal of Agricultural and Food Chemistry, vol. 46, no. 10, pp. 3952-3957, 1998.

[29] G. L. Ellman, K. D. Courtney, V. Andres Jr., and R. M. Featherstone, "A new and rapid colorimetric determination of acetylcholinesterase activity," Biochemical Pharmacology, vol. 7, no. 2, pp. 88-95, 1961.

[30] G. Oboh, A. O. Ademosun, P. O. Ayeni, O. S. Omojokun, and F. Bello, "Comparative effect of quercetin and rutin on $\alpha$-amylase, $\alpha$-glucosidase, and some pro-oxidant-induced lipid peroxidation in rat pancreas," Comparative Clinical Pathology, vol. 24, no. 5, pp. 1103-1110, 2015.

[31] B. Gullon, M. E. Pintado, J. A. Pérez-Álvarez, and M. ViudaMartos, "Assessment of polyphenolic profile and antibacterial activity of pomegranate peel (Punica granatum) flour obtained from co-product of juice extraction," Food Control, vol. 59, pp. 94-98, 2015.

[32] Z. Y. Zhu, F. Dong, X. Liu et al., "Effects of extraction methods on the yield, chemical structure and anti-tumor activity of polysaccharides from Cordyceps gunnii mycelia," Carbohydrate Polymers, vol. 140, pp. 461-471, 2016.

[33] J. Chen, X. Zhang, D. Huo et al., "Preliminary characterization, antioxidant and $\alpha$-glucosidase inhibitory activities of polysaccharides from Mallotus furetianus," Carbohydrate Polymers, vol. 215, pp. 307-315, 2019.
[34] N. Hammami, A. B. Gara, K. Bargougui, H. Ayedi, F. B. Abdalleh, and K. Belghith, "Improved in vitro antioxidant and antimicrobial capacities of polysaccharides isolated from Salicornia Arabica," International Journal of Biological Macromolecules, vol. 120, no. Part B, pp. 2123-2130, 2018.

[35] X. Xu, P. Chen, L. Zhang, and H. Ashida, "Chain structures of glucans from Lentinus edodes and their effects on NO production from RAW 264.7 macrophages," Carbohydrate Polymers, vol. 87, no. 2, pp. 1855-1862, 2012.

[36] D. Stewart, H. M. Wilson, P. L. Hendra, and I. M. Morrison, "Fourier-transform infrared and Raman spectroscopic study of biochemical and chemical treatments of oak wood (Quercus rubra) and barley (Hordeum vulgare) straw," Journal of Agricultural and Food Chemistry, vol. 43, no. 8, pp. 2219-2225, 1995.

[37] M. Kačuráková, N. Wellner, A. Ebringerová, Z. Hromádková, R. H. Wilson, and P. S. Belton, "Characterisation of xylantype polysaccharides and associated cell wall components by FT-IR and FT-Raman spectroscopies," Food Hydrocolloids, vol. 13, no. 1, pp. 35-41, 1999.

[38] Z. Chai, W. Huang, X. Zhao, H. Wu, X. Zeng, and C. Li, “Preparation, characterization, antioxidant activity and protective effect against cellular oxidative stress of polysaccharide from Cynanchum auriculatum Royle ex Wight," International Journal of Biological Macromolecules, vol. 119, pp. 1068-1076, 2018.

[39] Q. Zhao, B. Dong, J. Chen et al., "Effect of drying methods on physicochemical properties and antioxidant activities of wolfberry (Lycium barbarum) polysaccharide," Carbohydrate Polymers, vol. 127, pp. 176-181, 2015.

[40] R. Taylor and H. E. Conrad, "Stoichiometric depolymerization of polyuronides and glycosaminoglycuronans to monosaccharides following reduction of their carbodiimide-activated carboxyl group," Biochemistry, vol. 11, pp. 1383-1388, 2002.

[41] B. H. Wang, J. J. Cao, B. Zhang, and H. Q. Chen, "Structural characterization, physicochemical properties and $\alpha$-glucosidase inhibitory activity of polysaccharide from the fruits of wax apple," Carbohydrate Polymers, vol. 211, pp. 227-236, 2019.

[42] E. I. Nep and B. R. Conway, "Characterization of grewia gum, a potential pharmaceutical excipient," Journal of Excipients and Food Chemicals, vol. 1, pp. 30-40, 2010.

[43] K. P. Wang, J. Wang, Q. Li et al., "Structural differences and conformational characterization of five bioactive polysaccharides from Lentinus edodes," Food Research International, vol. 62, pp. 223-232, 2014.

[44] X. Chen, H. Zhang, W. Du et al., "Comparison of different extraction methods for polysaccharides from Crataegus pinnatifida Bunge," International Journal of Biological Macromolecules, vol. 150, pp. 1011-1019, 2019.

[45] W. Wang, X. Li, X. Bao, L. Gao, and Y. Tao, "Extraction of polysaccharides from black mulberry fruit and their effect on enhancing antioxidant activity," International Journal of Biological Macromolecules, vol. 120, no. Part B, pp. 1420-1429, 2018.

[46] H. Chen, M. Zhang, and B. Xie, "Quantification of uronic acids in tea polysaccharide conjugates and their antioxidant properties," Journal of Agricultural and Food Chemistry, vol. 52, no. 11, pp. 3333-3336, 2004.

[47] L. Tian, Y. Zhao, C. Guo, and X. Yang, “A comparative study on the antioxidant activities of an acidic polysaccharide and various solvent extracts derived from herbal Houttuynia 
cordata," Carbohydrate Polymers, vol. 83, no. 2, pp. 537-544, 2011.

[48] M. S. Blois, "Antioxidant determinations by the use of a stable free radical,” Nature, vol. 181, no. 4617, pp. 1199-1200, 1958.

[49] I. Rjeibi, A. Feriani, A. B. Saad et al., "Lycium europaeum Linn as a source of polysaccharide with in vitro antioxidant activities and in vivo anti-inflammatory and hepatonephroprotective potentials," Journal of Ethnopharmacology, vol. 225, pp. 116-127, 2018.

[50] C. Liu, J. Chang, L. Zhang, J. Zhang, and S. Li, "Purification and antioxidant activity of a polysaccharide from bulbs of Fritillaria ussuriensis Maxim," International Journal of Biological Macromolecules, vol. 50, no. 4, pp. 1075-1080, 2012.

[51] N. Fakhfakh, O. Abdelhedi, H. Jdir, M. Nasri, and N. Zouari, "Isolation of polysaccharides from Malva aegyptiaca and evaluation of their antioxidant and antibacterial properties," International Journal of Biological Macromolecules, vol. 105, Part 2, pp. 1519-1525, 2017.

[52] J. Wang, S. Hu, S. Nie, Q. Yu, and M. Xie, "Reviews on mechanisms of in vitro antioxidant activity of polysaccharides," Oxidative Medicine and Cellular Longevity, vol. 2016, 13 pages, 2016.

[53] L. Chun-hui, W. Chang-hai, X. Zhi-liang, and W. Yi, "Isolation, chemical characterization and antioxidant activities of two polysaccharides from the gel and the skin of Aloe barbadensis Miller irrigated with sea water," Process Biochemistry, vol. 42, no. 6, pp. 961-970, 2007.

[54] V. N. Talesa, "Acetylcholinesterase in Alzheimer's disease," Mechanisms of Ageing and Development, vol. 122, no. 16, pp. 1961-1969, 2001.

[55] L. E. Collins, N. E. Paul, S. F. Abbas et al., "Oral tremor induced by galantamine in rats: a model of the parkinsonian side effects of cholinomimetics used to treat Alzheimer's disease," Pharmacology Biochemistry and Behavior, vol. 99, no. 3, pp. 414-422, 2011.

[56] E. Esposito and S. Cuzzocrea, "New therapeutic strategy for Parkinson's and Alzheimer's disease," Current Medicinal Chemistry, vol. 17, no. 25, pp. 2764-2774, 2010.

[57] Z. Y. Cheng, L. L. Lou, P. Y. Yang et al., "Seven new neuroprotective sesquineolignans isolated from the seeds of Crataegus pinnatifida," Fitoterapia, vol. 133, pp. 225-230, 2019.

[58] X. X. Huang, M. Bai, L. Zhou et al., "Food byproducts as a new and cheap source of bioactive compounds: lignans with antioxidant and anti-inflammatory properties from Crataegus pinnatifida seeds," Journal of Agricultural and Food Chemistry, vol. 63, no. 32, pp. 7252-7260, 2015.

[59] M. Ali, S. Muhammad, M. R. Shah et al., "Neurologically potent molecules from Crataegus oxyacantha; isolation, anticholinesterase inhibition, and molecular docking," Frontiers in Pharmacology, vol. 8, p. 327, 2017.

[60] X. Liu, J. Bian, D. Li et al., "Structural features, antioxidant and acetylcholinesterase inhibitory activities of polysaccharides from stem of Physalis alkekengi L.," Industrial Crops and Products, vol. 129, pp. 654-661, 2019.

[61] W. Yang, Y. Fang, J. Liang, and Q. Hu, "Optimization of ultrasonic extraction of Flammulina velutipes polysaccharides and evaluation of its acetylcholinesterase inhibitory activity," Food Research International, vol. 44, no. 5, pp. 1269-1275, 2011.
[62] C. Chen, L. J. You, A. M. Abbasi, X. Fu, R. H. Liu, and C. Li, "Characterization of polysaccharide fractions in mulberry fruit and assessment of their antioxidant and hypoglycemic activities in vitro," Food \& Function, vol. 7, no. 1, pp. 530-539, 2016.

[63] N. Y. Yoon, D. N. Ngo, and S. K. Kim, "Acetylcholinesterase inhibitory activity of novel chitooligosaccharide derivatives," Carbohydrate Polymers, vol. 78, no. 4, pp. 869-872, 2009.

[64] Q. Meng, F. Chen, T. Xiao, and L. Zhang, "Inhibitory effects of polysaccharide from Diaphragma juglandis fructus on $\alpha$-amylase and $\alpha$-d-glucosidase activity, streptozotocin-induced hyperglycemia model, advanced glycation end-products formation, and $\mathrm{H}_{2} \mathrm{O}_{2}$-induced oxidative damage," International Journal of Biological Macromolecules, vol. 124, pp. 1080$1089,2019$.

[65] J. K. Yan, Y. Y. Wang, W. Y. Qiu, L. X. Wu, Z. C. Ding, and W. D. Cai, "Purification, structural characterization and bioactivity evaluation of a novel proteoglycan produced by Corbicula fluminea," Carbohydrate Polymers, vol. 176, pp. 11-18, 2017.

[66] Y. Xu, Y. Guo, Y. Gao et al., "Seperation, characterization and inhibition on $\alpha$-glucosidase, $\alpha$-amylase and glycation of a polysaccharide from blackcurrant fruits," LWT-Food Science and Technology, vol. 93, pp. 16-23, 2018.

[67] C. Nie, P. Zhu, M. Wang, S. Ma, and Z. Wei, "Optimization of water-soluble polysaccharides from stem lettuce by response surface methodology and study on its characterization and bioactivities," International Journal of Biological Macromolecules, vol. 105, Part 1, pp. 912-923, 2017.

[68] I. Khemakhem, O. Abdelhedi, I. Trigui, M. A. Ayadi, and M. Bouaziz, "Structural, antioxidant and antibacterial activities of polysaccharides extracted from olive leaves," International Journal of Biological Macromolecules, vol. 106, pp. 425-432, 2018.

[69] C. Cueva, M. V. Moreno-Arribas, P. J. Martín-Álvarez et al., "Antimicrobial activity of phenolic acids against commensal, probiotic and pathogenic bacteria," Research in Microbiology, vol. 161, no. 5, pp. 372-382, 2010.

[70] F. He, Y. Yang, G. Yang, and L. Yu, "Studies on antibacterial activity and antibacterial mechanism of a novel polysaccharide from Streptomyces virginia H03," Food Control, vol. 21, no. 9, pp. 1257-1262, 2010.

[71] I. Khlusov, E. Avdeeva, V. Shupletsova et al., "Comparative in vitro evaluation of antibacterial and osteogenic activity of polysaccharide and flavonoid fractions isolated from the leaves of Saussurea controversa," Molecules, vol. 24, no. 20, p. 3680, 2019.

[72] M. Sardarodiyan, A. Arianfar, A. M. Sani, and S. Naji-Tabasi, "Antioxidant and antimicrobial activities of water-soluble polysaccharide isolated from Balangu seed (Lallemantia royleana) gum," Journal of Analytical Science and Technology, vol. 10, no. 1, p. 17, 2019. 